\title{
Synthesis of Dipeptides and Ruthenium-Phenanthroline \\ Derivative for Photo Redox Studies
}

\author{
Gondi Sudershan Reddy ${ }^{1^{*}}$
}

\begin{abstract}
Affiliations:
${ }^{1}$ Department of Chemistry, National Taiwan Normal University, Taipei, Taiwan, 116 (ROC).

a Correspondence to: gondisr@gmail.com
\end{abstract}

\begin{abstract}
This paper describes the synthesis and characterization of a dipeptides and ruthenium phenanthroline-amine for the study of photoinitiated electron transfer (ET) in dipeptides were described.
\end{abstract}

Key words: Photoredox, Ruthenium-phenanthroline-amine, Dipeptides, Electron Transfer.

Introduction: Photo physical properties of ruthenium complexes are much attention in recent years for its wide application is the study of electron transfer ${ }^{1,2}$, molecular assemblies $^{3,4}$ and amide bridges containing peptides and proteins. groups $s^{5,6}$. A key feature of these applications is the electron distribution of ruthenium complexes measured by its acid dissociation constants of the ground and excited states. Several research group ${ }^{7,8,9,10}$ explored excited-state charge distribution and electron transfer (ET) in ruthenium complexes especially in combination with proteins and polypeptides

Present work: In continuing our work on photoredox, we succeeded in synthesizing the Fluorescence Probe ${ }^{11}$ to investigate cytochrome $c$ folding kinetics and Synthesizing the photoredox ruthenium bipyridyl were linked with biomolecules having oxidative quencher, 
viologen ${ }^{12}$, herein we disclosed design of Ruthenium-Dipeptide molecule 1 (figure-1) which allows for many variations of the ruthenium Phenanthroline-5-Amine $\mathbf{3}$ and dipeptide structures 2, The synthetic routes are straightforward and very manageable, it is possible to use commercially available L-amino acids as enantiomerically enriched starting materials.

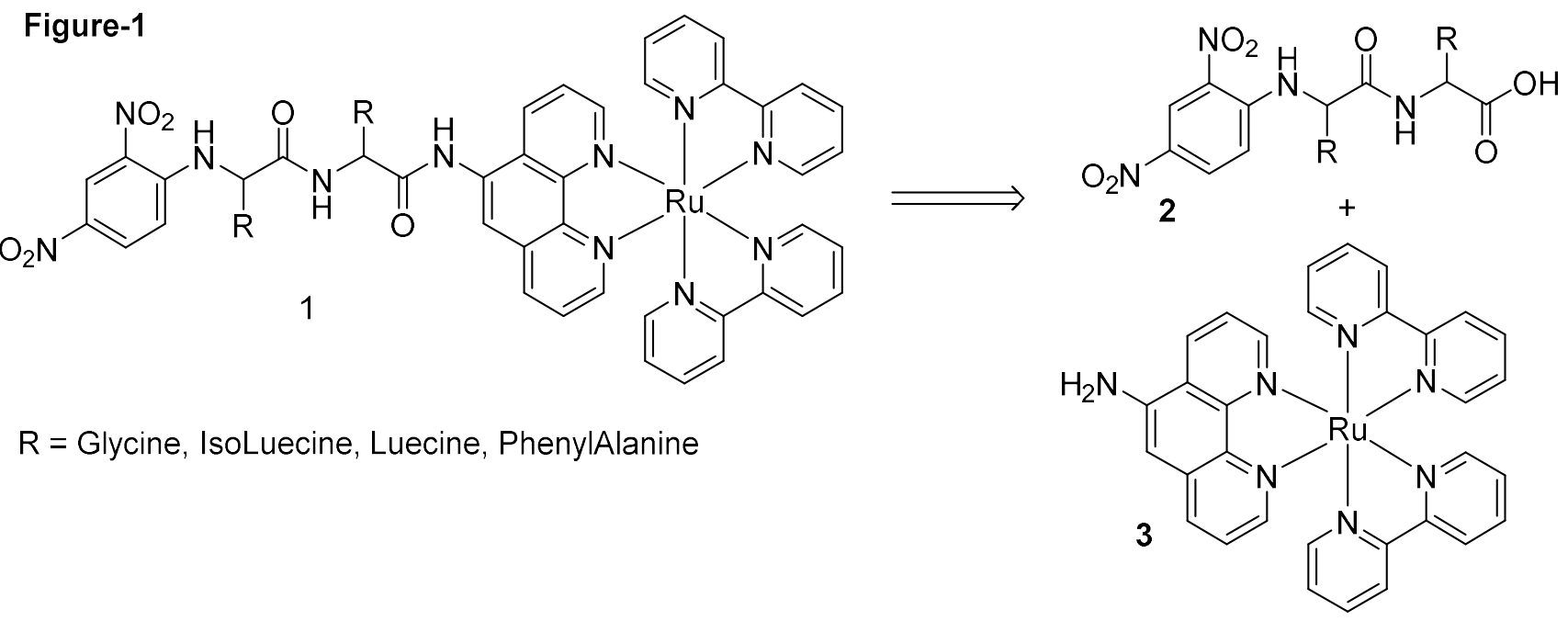

Synthesis Part: The dinitro-fluorobenzene were treated with glycine under base condition to get product ${ }^{13} \mathbf{4}$, which is treated with oxalyl chloride to get acid chloride product ${ }^{14} \mathbf{5}$. The free glycine ester ${ }^{15} \mathbf{6}$ is prepared with base treatment in 90 yield. On combining the $\mathbf{5}$ with $\mathbf{6}$ to gives the dipeptide ${ }^{16}$ ester 7 in $60 \%$ yield. The diester 7 on saponification gives dipeptide ${ }^{17}$ $2 a$ in $75 \%$ yield. (scheme-1)

\section{Scheme-1}

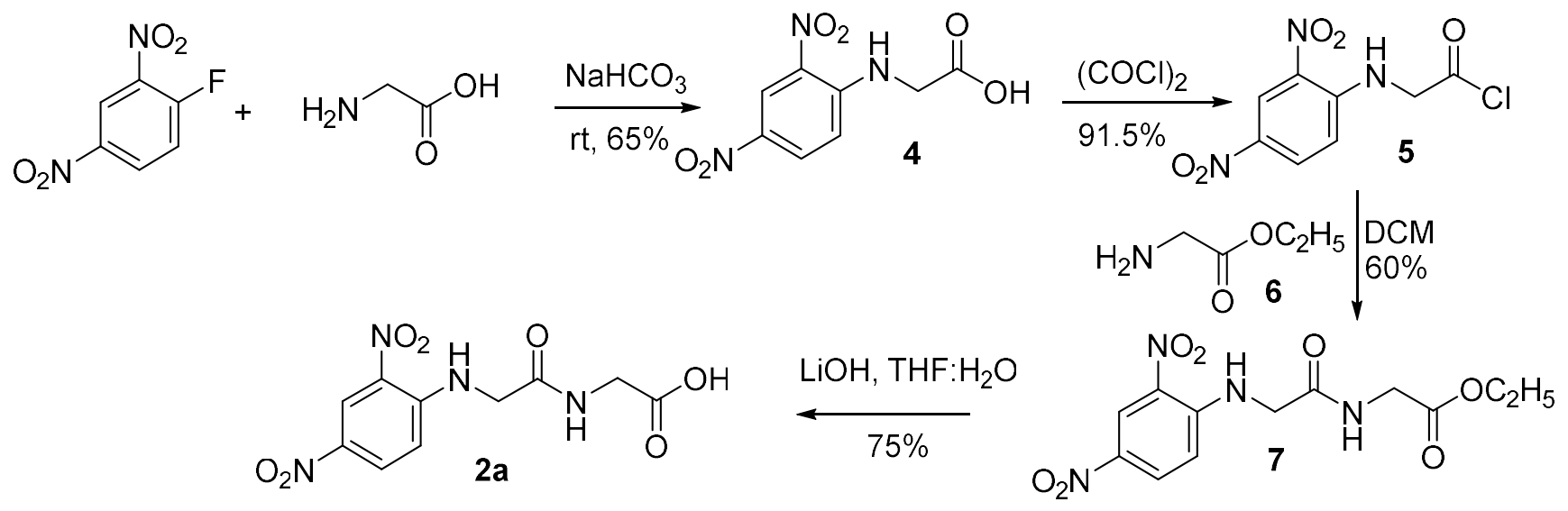


Alternatively, dipeptide acid $2 \mathbf{a}$ was prepared from phthalimido ethanol ${ }^{18} \mathbf{8}$, which on oxidation to acid product ${ }^{19} \mathbf{9}$ followed by acid chloride ${ }^{20}$ conversion gives 10 in $91 \%$ yield, which was esterified to MPM ester ${ }^{21} 11$ by using MPM-OH, the phthalide group is cleaved by $40 \%$ monomethyl amine to get glycine MPM ester 2212 in 55\% yield.(scheme-2)

\section{Scheme-2}<smiles>COc1ccc(COC(=O)CN2C(=O)c3ccccc3C2=O)cc1COC(=O)CN1C(=O)c2ccccc2C1=O</smiles>

Similarly, corresponding symmetrical dipeptides from isoleucine ${ }^{23,24}$, leucine ${ }^{25-27}$ and phenylalanine ${ }^{28-30}$ were synthesized in four steps each to get $\mathbf{2 b}, \mathbf{2} \mathbf{c}$, and $\mathbf{2 d}$ respectively.

\section{Scheme-3}<smiles>O=[N+]([O-])c1ccc(F)c([N+](=O)[O-])c1</smiles>

13-16, 2b, $\mathrm{R}=\mathrm{CH}\left(\mathrm{CH}_{3}\right) \mathrm{C}_{2} \mathrm{H}_{5}$ 17-20, 2c, $\mathrm{R}=\mathrm{CH}_{2} \mathrm{CH}\left(\mathrm{CH}_{3}\right)_{2}$ 21-24, 2d, $\mathrm{R}=\mathrm{CH}_{2} \mathrm{Ph}$<smiles>[R]C(NC(=O)C([R])Nc1ccc([N+](=O)[O-])cc1[N+](=O)[O-])C(=O)O</smiles>

$2 b, 78 \%$

2c, $75 \%$

2d, $71 \%$

$13,70 \%$

$17,75 \%$

$21,75 \%$<smiles>[R]C(Nc1ccc([N+](=O)[O-])cc1[N+](=O)[O-])C(=O)OC([R])C(=O)OC(C)C(=O)OCc1ccc([N+](=O)[O-])cc1[N+](=O)[O-]</smiles>

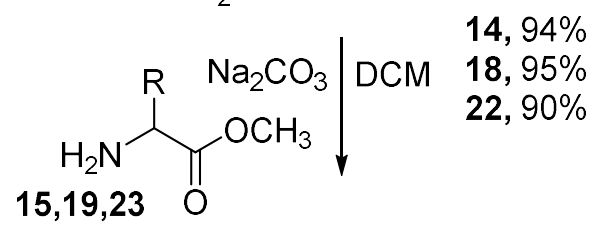
$5,19,23$<smiles>[R]C(Nc1ccc([N+](=O)[O-])cc1[N+](=O)[O-])C(=O)NC([R])C(=O)OC</smiles>

$16,75 \%$

$20,75 \%$

24, $71 \%$

Page $\mathbf{3}$ of $\mathbf{2 3}$ 
The phenanthrene was on nitration gives phenthroline-5-nitro ${ }^{31}$ in $32 \%$ yield. The corresponding amine was synthesized in two different methods, palladium/charcoal ${ }^{32}$ and stannous chloride 33 in $90 \%$ and $51 \%$ respectively. (scheme-4)

\section{Scheme-4}<smiles>c1cnc2c(c1)ccc1cccnc12</smiles>

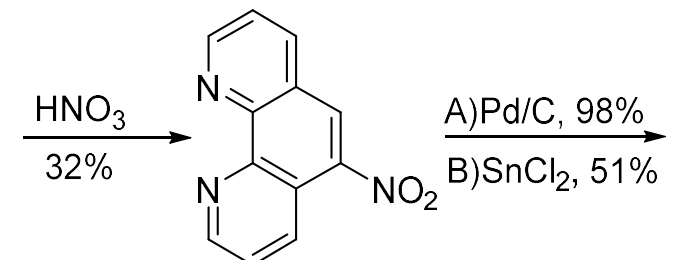

25<smiles>Nc1cc2cccnc2c2ncccc12</smiles>

26

Ruthenium carbonate is prepared in two steps by treating 2,2-bipyridyl with ruthenium trichloride to obtained intermediate product ${ }^{34}$ in $40 \%$ yield, which on treated with sodium carbonate under Argon atmosphere gives ruthenium carbonate ${ }^{35}$ in $67 \%$ yield. Ruthenium carbonate on treated with compounds $\mathbf{2 6}$ under heating condition to obtained the pure product ${ }^{36}$ in $90 \%$ yield. (scheme5).

\section{Scheme-5}<smiles>c1ccc(-c2ccccn2)nc1</smiles>

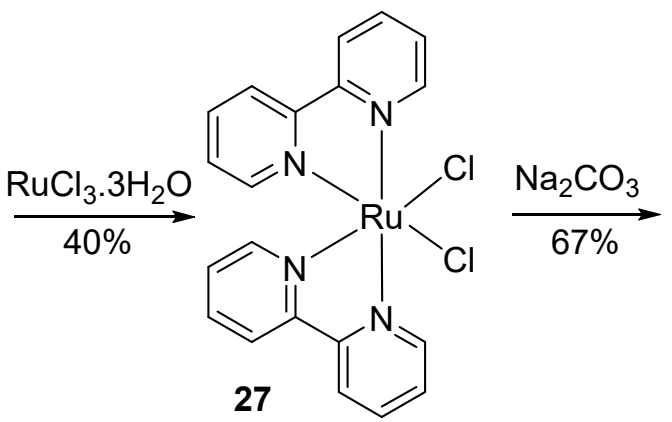<smiles>Nc1cc2cccnc2c2ncccc12</smiles><smiles></smiles> 
Conclusion: In summary, A manageable synthetic route for dipeptides and rutheniumphenanthrene-amine was established. This work provides valuable information for the discovery of novel strategies in exploring novel molecules having combined properties of electronic channel and photoredox properties of ruthenium and its amide coupling with dipeptides suitable for biological applications.

Experimental parameters: All reagents were purchased from commercial sources and used without any further purification. Technical solvents were used unless otherwise stated. Anhydrous solvents were obtained by passing solvent through columns of molecular sieves in a solvent purification system. Flash chromatography employed 230-400 mesh silica gel. Solvents used for chromatography are quoted as volume/volume ratios. Analytical thin layer chromatography was performed using silica gel plates precoated with silica gel 60 F254 (0.2 $\mathrm{mm}$ ) using UV light and $10 \%$ ethanolic solution phosphomolybdic acid dip to visualize the products. ${ }^{1} \mathrm{H}$ NMR spectra were recorded at $298 \mathrm{~K}$ unless otherwise stated using Varian VXR (200 MHz) spectrometers. Data is expressed in parts per million (ppm) downfield shift

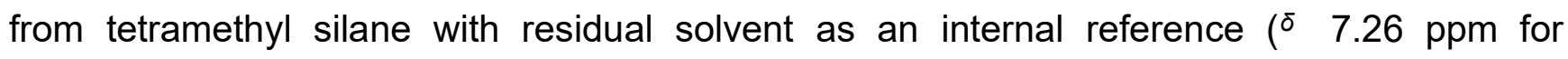
chloroform) and is reported as position ( ${ }^{\delta}$ in ppm), multiplicity $(s=$ singlet, $d=$ doublet, $t=$ triplet, $\mathrm{q}=$ quartet $=$ multiplet), coupling constant $(\mathrm{J}$ in $\mathrm{Hz}$ ) and integration (number of protons). ${ }^{13} \mathrm{C}$ NMR spectra were recorded at $298 \mathrm{~K}$ unless otherwise stated using Bruker Avance III $100 \mathrm{MHz}$ spectrometers with complete proton decoupling. Data is expressed in parts per million (ppm) downfield shifts relative to the internal reference $(\delta 77.2 \mathrm{ppm}$ for the central peak of deuterated chloroform) and is reported as position ( ${ }^{\delta}$ in ppm). IR spectra were recorded on a Perkin Elmer 688 spectrometer. Mass spectra were obtained on a Shimadzu QP 1000 spectrometer. High resolution mass spectra (HRMS) were recorded using 
electrospray ionization on a Time of Flight (TOF) mass spectrometer at National Taiwan University.

(2,4-Dinitro-phenylamino)-acetic acid: (4) Dissolved $6.0 \mathrm{~g}(79 \mathrm{mmol})$ of glycine in $100 \mathrm{~mL}$<smiles>O=C(O)CNc1ccc([N+](=O)[O-])cc1[N+](=O)[O-]</smiles>
of $0.1 \mathrm{M}$ sodium bicarbonate solution in a beaker. Added $160 \mathrm{mmol}$ (3.0 g/2.0 mL) of 2,4-dinitrofluorobenzene solution (in $10 \mathrm{~mL}$ of acetone) over a period of 5 minutes. Stir for 4 hours at room temperature. Distilled to half of its volume to get residue and neutralized with $2.0 \mathrm{M} \mathrm{HCl}(30$ $\mathrm{mL})$ and filtered, washed the yellow solid with water $(10 \mathrm{~mL} X 2)$ followed by hexane $(10 \mathrm{~mL}$ $X$ 2). Transferred the solid to single neck flask and add benzene $(10 \mathrm{~mL} X 2)$, concentrated on rota evaporator under pressure to obtain $2.5 \mathrm{~g}$ of yellow solid product 4 in $65 \%$ yield. Melting point is $192-196^{\circ} \mathrm{C} .{ }^{1} \mathrm{H}$ NMR $(200 \mathrm{MHz}$, acetone-d6): $9.02(\mathrm{~d}, 1 \mathrm{H}, J=2.6 \mathrm{~Hz}), 8.37-$ $8.31(\mathrm{dd}, 1 \mathrm{H}, J=2.8 \& 6.6 \mathrm{~Hz}), 7.18(\mathrm{~d}, 1 \mathrm{H}, J=9.2 \mathrm{~Hz}), 4.48-4.45$ (dis-d, $2 \mathrm{H}, J=2.6 \& 7.2$ Hz). Mass: m/z. $241(M+)$.

(2,4-Dinitro-phenylamino)-acetyl chloride: (5): Suspended $5.0 \mathrm{~g}(24.3 \mathrm{mmol})$ of $\mathrm{N}-(2,4-$<smiles>O=C(Cl)CNc1ccc([N+](=O)[O-])cc1[N+](=O)[O-]</smiles>
Dintrophenyl)-Glycine in benzene $(50 \mathrm{~mL})$, Added $24.3 \mathrm{mmol}(3.1 \mathrm{~g} /$ $2.2 \mathrm{~mL}$ ) of oxalyl chloride drop wise over a period of 5 minutes under nitrogen atmosphere. Stirred at room temperature for 2 hours. Concentrated on rota evaporator to get $5.0 \mathrm{~g}$ of reddish solid product $\mathbf{5}$ in $91.5 \%$ yield. Melting point is $82-84^{\circ} \mathrm{C} .{ }^{1} \mathrm{H}$ NMR $\left(200 \mathrm{MHz}, \mathrm{CDCl}_{3}\right):{ }^{\delta} 9.17(\mathrm{~d}, 1 \mathrm{H}, J=2.6 \mathrm{~Hz}), 9.17-9.16$ $(\mathrm{m}, 1 \mathrm{H}, \mathrm{NH}), 8.39-8.37(\mathrm{dd}, 1 \mathrm{H}, J=2.0 \& 6.2 \mathrm{~Hz}), 6.75(\mathrm{~d}, 1 \mathrm{H}, J=9.2 \mathrm{~Hz}), 4.65(\mathrm{~d}, 2 \mathrm{H}, J=$ $6.2 \mathrm{~Hz})$.

Ethyl-2-aminoacetate: (6): Dissolve $5.0 \mathrm{~g}(35.8 \mathrm{mmol})$ of ethyl 2-aminoacetate $\mathrm{HCl}$ salt in $\mathrm{H}_{2} \mathrm{~N} \stackrel{\mathrm{O}}{\mathrm{O}}_{\mathrm{OC}_{2} \mathrm{H}_{5}}$ $100 \mathrm{~mL}$ of $1.0 \mathrm{M}$ solution of sodium carbonate in a beaker. Stirred the 6 
(100 $\mathrm{mL} \mathrm{X} \mathrm{2),} \mathrm{Washed} \mathrm{the} \mathrm{organic} \mathrm{layer} \mathrm{with} \mathrm{brine} \mathrm{solution}(200 \mathrm{~mL})$, dried over $\mathrm{MgSO}_{4}$ and filter. Concentrated under reduced pressure to get $1.8 \mathrm{~g}$ of product 6 in $50 \%$ yield. ${ }^{1} \mathrm{H}$ NMR (200 MHz, $\left.\mathrm{CDCl}_{3}\right):{ }^{\delta} 4.16-4.11(\mathrm{~m}, 2 \mathrm{H}), 3.33(\mathrm{~d}, 2 \mathrm{H}, \mathrm{J}=2.0 \mathrm{~Hz}), 1.23-1.14(\mathrm{~m}, 3 \mathrm{H})$.

[2-(2,4-Dinitro-phenylamino)-acetylamino]-acetic acid ethyl ester: (7): Suspended $1.74 \mathrm{~g}$<smiles>COC(=O)CNC(=O)CNc1ccc([N+](=O)[O-])cc1[N+](=O)[O-]</smiles>
(12.4 mmol) of ethyl ester 6 in dichloromethane $(30 \mathrm{~mL})$ under nitrogen atmosphere. Cool to $0^{\circ} \mathrm{C}$ and add $2.0 \mathrm{~g}$ (19.0 mmol) of sodium carbonate at $0^{\circ} \mathrm{C}$ and stir for $1 \mathrm{~h}$. Drop wise addition of $2.5 \mathrm{~g}(9.6 \mathrm{mmol})$ of acid chloride $\mathbf{5}$ solution (10 $\mathrm{mL}$ of dichloromethane) over a period of 15 minutes. Maintained at room temperature for 6 hours and poured the reaction mass into beaker containing $250 \mathrm{~mL}$ of water. Extracted with dichloromethane (50 $\mathrm{mL} \times 2$ ). Washed the combined organic layer with saturated $\mathrm{NaHCO}_{3}$ solution, brine solution, dried over $\mathrm{MgSO}_{4}$, and filtered. Concentrated under reduced pressure and purified by column chromatography to obtain the $1.8 \mathrm{~g}$ of product 7 in $60 \%$ yield. ${ }^{1} \mathrm{H} \mathrm{NMR}\left(200 \mathrm{MHz}, \mathrm{CDCl}_{3}\right)$ : $\delta$ $9.15(\mathrm{~d}, 1 \mathrm{H}, J=2.8 \mathrm{~Hz}), 8.95(\mathrm{~m}, 1 \mathrm{H}, \mathrm{NH}), 8.34-8.28(\mathrm{dd}, 1 \mathrm{H}, J=6.2 \& 13.0 \mathrm{~Hz}), 6.80(\mathrm{~d}, 1 \mathrm{H}$, $J=8.8 \mathrm{~Hz}), 6.36(\mathrm{~m}, 1 \mathrm{H}, \mathrm{NH}), 4.22-4.02(\mathrm{t}, 2 \mathrm{H}, J=5.2 \& 6.6 \mathrm{~Hz}), 1.30-1.23(\mathrm{t}, 3 \mathrm{H}, J=7.2 \&$ 14.2 Hz). Mass m/z: $326(M+)$.

[2-(2,4-Dinitro-phenylamino)-acetylamino]-acetic acid. (2a): Method-A: Dissolved $1.5 \mathrm{~g}$<smiles>O=C(O)CNC(=O)CNc1ccc([N+](=O)[O-])cc1[N+](=O)[O-]</smiles>
(4.5 mmol) of ethyl ester 7 in THF: water $10 \mathrm{~mL}: 5 \mathrm{~mL}$. Added $386 \mathrm{mg}(12.0 \mathrm{mmol})$ of lithium hydroxide portion wise over a period of 10 minutes. Stirred at room temperature for 4 hours. Initially it was dark red which gradually turns to pale red (after 2 hours) and yellow (after 4 hours). Concentration on rota evaporator under reduced pressure to remove the THF. Dissolved the residue in $15 \mathrm{~mL}$ of water and neutralize with conc. $\mathrm{HCl}(5 \mathrm{~mL})$ and filtered, washed the yellow solid with water $(10 \mathrm{~mL} X 2)$ followed by hexane $(10 \mathrm{~mL} X 2)$. Transferred 
the solid to single neck flask and added benzene (10 $\mathrm{mL} X 2)$, concentrated on rota evaporator under pressure to obtain $1.0 \mathrm{~g}$ of yellow solid $\mathbf{2 a}$ in $75 \%$ yield. Melting point is 194-195ㄷ. ${ }^{1} \mathrm{H}$ NMR (200 MHz, Acetone-d6): ${ }^{\delta} 9.26(\mathrm{~m}, 1 \mathrm{H}, \mathrm{NH}), 8.99(\mathrm{~d}, 1 \mathrm{H}, \mathrm{J}=2.6 \& 6.6$ $\mathrm{Hz}), 8.35-8.29((\mathrm{dd}, 1 \mathrm{H}, J=2.6 \& 6.6 \mathrm{~Hz}), 7.88(\mathrm{~m}, 1 \mathrm{H}, \mathrm{NH}), 7.07(\mathrm{~d}, 1 \mathrm{H}, J=9.4 \mathrm{~Hz}), 4.37$ (dd, $2 \mathrm{H}, J=2.8 \& 6.6 \mathrm{~Hz}), 4.05(\mathrm{~d}, 2 \mathrm{H}, J=5.6 \mathrm{~Hz})$. Mass m/z: $298(\mathrm{M}+)$.

Method-B: Suspended $1.0 \mathrm{~g}$ (5.1 mmol) of MPM-ester 12 in dichloromethane $(30 \mathrm{~mL})$ under nitrogen atmosphere. Cool to $0^{\circ} \mathrm{C}$ and add $1.1 \mathrm{~g}(10.2 \mathrm{mmol})$ of sodium carbonate at $0^{\circ} \mathrm{C}$ and stir for $1 \mathrm{~h}$. Drop wise addition of $1.2 \mathrm{~g}(4.6 \mathrm{mmol})$ of acid chloride 5 solution (10 $\mathrm{mL}$ of dichloromethane) over a period of 15 minutes. Maintained at room temperature for 6 hours and poured the reaction mass into beaker containing $250 \mathrm{~mL}$ of water. Extracted with dichloromethane $(50 \mathrm{~mL} \times 2)$. Added $10 \mathrm{ml}$ of trifluoro acetic acid and stirred for 2 hours at room temperature. Concentrated to get residue. Extracted with dichloromethane $(50 \mathrm{~mL} \times 2)$. Washed the combined organic layer with saturated $\mathrm{NaHCO}_{3}$ solution, brine solution, dried over $\mathrm{MgSO}_{4}$, and filtered. Concentrated under reduced pressure and purified by column chromatography to obtain the $760 \mathrm{mg}$ of product 7 in $50 \%$ yield.

2-(2-Hydroxy-ethyl)-isoindole-1,3-dione: (8): Charged $37 \mathrm{~g}$ (250 mmol) of phthalic<smiles>O=C1c2ccccc2C(=O)N1CCO</smiles>
anhydride in a 1 L-R.B. equipped with reflux condenser. Poured $15 \mathrm{~g}$ (250 mmol) of 2 -amino ethanol. Heated at $90-100^{\circ} \mathrm{C}$. Initially the reaction is vigorous and turns from pasty to liquid. Stirred for 1 hour at same temperature. Poured $100 \mathrm{~mL}$ of water and increase the temperature to $110-120^{\circ} \mathrm{C}$. Maintained for 30 minutes. Poured the hot liquid mass into beaker, allowed cooling to RT. Filtered and washed with water $(250 \mathrm{~mL})$ to obtain the product $40 \mathrm{~g}$ of product 8 in $83.4 \%$ yield. ${ }^{1} \mathrm{H}$ NMR $\left(200 \mathrm{MHz}, \mathrm{CDCl}_{3}\right)$ : ${ }^{\delta} 7.88-7.77(\mathrm{~m}, 2 \mathrm{H}), 7.75-7.70(\mathrm{~m}, 2 \mathrm{H}), 3.92(\mathrm{~m}, 4 \mathrm{H})$. Mass: $191(\mathrm{M}+)$. 
1,3-Dioxo-1,3-dihydro-isoindol-2-yl)-acetic acid: (9): Charged $25 \mathrm{~g}(131 \mathrm{~mol})$ of 2-<smiles>O=C(O)CN1C(=O)c2ccccc2C1=O</smilesPhthalimino ethanol 8 in a 3N-1L-RB equipped reflux. Poured $400 \mathrm{~mL}$ of water, $10 \mathrm{~mL}$ of glacial acetic acid. Added $30.1 \mathrm{~g}$ of $\mathrm{K}_{2} \mathrm{Cr}_{2} \mathrm{O}_{7}$ and stirred for 15 minutes. Dropwise addition of dilute sulfuric acid $(25.5 \mathrm{~g}$ in $100 \mathrm{~mL}$ of water) over 30 minutes. Heated the reaction mass at $70^{\circ} \mathrm{C}-100^{\circ} \mathrm{C}$ for 1 hour. (Initially it is suspension which turns to clear solution). Maintained at $100^{\circ} \mathrm{C}$ for 3 hours. Allowed cooling to RT. Concentrated to half off its volume, filtered and washed with water, dry in vacuum for 3 hours to obtain $22 \mathrm{~g}$ of white powder solid 9 in $82 \%$ yield. Melting point is $193-196^{\circ} \mathrm{C}$. Product is soluble in EtOAc, ether, acetone, methanol and Insoluble in DCM, chloroform, benzene, toluene, hexane, and water. ${ }^{1} \mathrm{H}$ NMR $\left(200 \mathrm{MHz}, \mathrm{CD}_{3} \mathrm{OD}\right):{ }^{\delta} 7.32-7.25$ (m, 4H), $3.68(\mathrm{~s}, 2 \mathrm{H})$. Mass: $205(\mathrm{M}+)$.

(1,3-Dioxo-1,3-dihydro-isoindol-2-yl)-acetyl chloride: (10): Charged $5 \mathrm{~g}$ (24 mmol) of 2-<smiles>O=C(Cl)CN1C(=O)c2ccccc2C1=O</smilesPhthalimido acetic acid in a R.B. flask and add toluene under nitrogen atmosphere. drop wise addition $2.2 \mathrm{ml} / 3.1 \mathrm{~g}(24 \mathrm{mmol})$ of oxalyl chloride for 5 minutes. Add one drop of DMF. Stirred at RT for 2 hours. Homogenous solution is formed. Concentrated on rota evaporator to get residue, which slowly turns to reddish solid $5 \mathrm{~g}$ of product 10 is obtained in 91.5 yield. ${ }^{1} \mathrm{H}$ NMR $(200 \mathrm{MHz}$, $\left.\mathrm{CDCl}_{3}\right):{ }^{\delta} 7.94-7.81(\mathrm{~m}, 2 \mathrm{H}), 7.79-7.25(\mathrm{~m}, 2 \mathrm{H}), 4.82(\mathrm{~s}, 2 \mathrm{H})$. Mass: $223(\mathrm{M}+)$.

(1,3-Dioxo-1,3-dihydro-isoindol-2-yl)-acetic acid 4-methoxy-benzyl ester: (11): Charged $2.76 \mathrm{~g}(20 \mathrm{mmol}, 0.9 \mathrm{eq})$ of 4-methoxy benzyl alcohol<smiles>COc1ccc(COC(=O)CN2C(=O)c3ccccc3C2=O)cc1</smiles>

in a R.B flask and cooled to $0^{\circ} \mathrm{C}$ and added $75 \mathrm{~mL}$ of DCM. Drop wise addition of $4.37 \mathrm{~mL} / 3.33 \mathrm{~g}$, $(33 \mathrm{mmol}$, 
1.5 eq) of TEA over a period 5 minutes. Stirred for 1 hour at RT and cool to $0^{\circ} \mathrm{C}$. Drop wise addition of $5.0 \mathrm{~g}(23 \mathrm{mmol})$ of acid chloride 10 over a period of 15 minutes. Stir for $0^{\circ} \mathrm{C}-\mathrm{RT}$ for 3 hours. Quenched with water and extracted with DCM, Washed the organic layer with $10 \% \mathrm{NaHCO}_{3}$, brine solution, dried over $\mathrm{MgSO}_{4}$ and filtered. Concentrated and Column chromatography purification give $5 \mathrm{~g}$ of product 11 in $70 \%$ yield. Rf value of MPMOH $(0.3)$ Product (0.6) in 40\% EtOAc in hexane. ${ }^{1} \mathrm{H}$ NMR $\left(200 \mathrm{MHz}, \mathrm{CDCl}_{3}\right):{ }^{\delta} 7.89-7.86(\mathrm{~m}, 2 \mathrm{H})$, 7.76-7.72 (m, 2H), $7.30(\mathrm{~d}, 2 \mathrm{H}, J=8.8 \mathrm{~Hz}), 6.86(\mathrm{~d}, 2 \mathrm{H}, J=8.8 \mathrm{~Hz}), 5.13(\mathrm{~s}, 2 \mathrm{H}), 4.45(\mathrm{~s}$, 2H), $3.80(\mathrm{~s}, 3 \mathrm{H})$. Mass: $325(\mathrm{M}+)$.

Amino-acetic acid 4-methoxy-benzyl ester: (12): Charged $5 \mathrm{~g}$ (15.3 mmol) of MPM ester<smiles>COc1ccc(COC(=O)CN)cc1</smiles>
11 in a R.B. flask and added $50 \mathrm{~mL}$ of chloroform. Added 25 $\mathrm{mL}$ of $40 \%$ of monomethylamine and stir at RT for 6 hours. Extracted with DCM (50 $\mathrm{ml} \times 2)$, washed the combined organic layer with $10 \% \mathrm{NaHCO}_{3}$, brine solution, dried over $\mathrm{MgSO}_{4}$ and filtered. Concentrated and column purification give $1.65 \mathrm{~g}$ of product 12 in $55 \%$ yield. ${ }^{1} \mathrm{H}$ NMR $\left(200 \mathrm{MHz}, \mathrm{CDCl}_{3}\right):{ }^{\delta} 8.45(\mathrm{br}-\mathrm{d}, 2 \mathrm{H}, \mathrm{NH}), 7.29(\mathrm{~d}, 2 \mathrm{H}, J=8.2 \mathrm{~Hz}), 6.89(\mathrm{~d}$, $2 \mathrm{H}, J=8.2 \mathrm{~Hz}), 5.28(\mathrm{~s}, 2 \mathrm{H}), 3.79(\mathrm{~s}, 3 \mathrm{H}), 3.31(\mathrm{~d}, 2 \mathrm{H}, J=3.8 \mathrm{~Hz})$.

2-(2,4-Dinitro-phenylamino)-3-methyl-pentanoic acid: (13): Dissolved $10.0 \mathrm{~g}$ (76 mmol) of<smiles>CCC(C)C(Nc1ccc([N+](=O)[O-])cc1[N+](=O)[O-])C(=O)O</smiles>
Isoluecine in $250 \mathrm{~mL}$ of $0.2 \mathrm{M}$ sodium bicarbonate solution in a beaker. Add $52 \mathrm{mmol}(9.64 \mathrm{~g} / 6.5 \mathrm{~mL}$ ) of 2,4-dinitrofluorobenzene solution (in $20 \mathrm{~mL}$ of acetone) over a period of 5 minutes. Stir for 4 hours at room temperature. Distilled to half of its volume to get residue and neutralize with $2.0 \mathrm{M} \mathrm{HCl}$ (30 $\mathrm{mL})$ and filtered, washed the yellow solid with water $(10 \mathrm{~mL} X 2)$ followed by hexane $(10 \mathrm{~mL}$ $X$ 2). Transferred the solid to single neck flask and add benzene (10 $\mathrm{mL} X 2)$, concentrated on rota evaporator under pressure to obtain $10.75 \mathrm{~g}$ of yellow solid product 13 in $70 \%$ yield. 
Product is freely soluble in methanol, ethanol, ethyl acetate, dichloromethane, chloroform, and hot benzene. ${ }^{1} \mathrm{H}$ NMR $\left(200 \mathrm{MHz}, \mathrm{CD}_{3} \mathrm{OD}\right):{ }^{\delta} 8.76(\mathrm{~d}, 1 \mathrm{H}, J=2.8 \mathrm{~Hz}), 7.98-7.92(\mathrm{dd}, 1 \mathrm{H}$, $J=2.8 \& 6.8 \mathrm{~Hz}), 6.60(\mathrm{~d}, 1 \mathrm{H}, J=10.0 \mathrm{~Hz}), 3.80(\mathrm{~d}, 1 \mathrm{H}, J=5.4 \mathrm{~Hz}), 1.82-1.52(\mathrm{~m}, 1 \mathrm{H}), 1.41-$ $1.21(\mathrm{~m}, 1 \mathrm{H}), 1.18-0.99(\mathrm{~m}, 1 \mathrm{H})$, 0.80-0.67 (m, 6H). Mass m/z: $297(\mathrm{M}+)$.

2-(2,4-Dinitro-phenylamino)-3-methyl-pentanoyl chloride (14): Suspended $2.0 \mathrm{~g}$ (4 mmol)<smiles>[Y4]C(CC)C(Nc1ccc([N+](=O)[O-])cc1[N+](=O)[O-])C(=O)Cl</smiles>
of $\mathrm{N}$ - (2,4-Dintrophenyl)-Isoleucine in benzene $(20 \mathrm{~mL})$, Added $5 \mathrm{mmol}$ $(0.63 \mathrm{~g} / 0.4 \mathrm{~mL})$ of oxalyl chloride drop wise over a period of 5 minutes under nitrogen atmosphere. Stir at room temperature for 2 hours. Concentrated on rota evaporator to get $2.0 \mathrm{~g}$ of reddish solid product 14 in $94.3 \%$ yield. ${ }^{1} \mathrm{H}$ $\operatorname{NMR}\left(200 \mathrm{MHz}, \mathrm{CDCl}_{3}\right):{ }^{\delta} 9.08(\mathrm{~d}, 1 \mathrm{H}, J=2.6 \mathrm{~Hz}), 8.72(\mathrm{~d}, 1 \mathrm{H}, J=7.0 \mathrm{~Hz}), 8.27-8.21$ (dd, $1 \mathrm{H}, J=2.6 \& 6.8 \mathrm{~Hz}), 6.68(\mathrm{~d}, 1 \mathrm{H}, J=10.6 \mathrm{~Hz}), 4.31-4.24(\mathrm{dd}, 1 \mathrm{H}, J=6.2 \& 14.0 \mathrm{~Hz}), 2.20-$ $2.10(\mathrm{~m}, 1 \mathrm{H}), 1.82-1.62(\mathrm{~m}, 1 \mathrm{H}), 1.40-1.20(\mathrm{~m}, 1 \mathrm{H}), 1.09(\mathrm{~d}, 3 \mathrm{H}, J=1.8 \& 5.2 \mathrm{~Hz}), 0.97-0.89$ (t, $3 \mathrm{H}, J=7.2 \& 14.6 \mathrm{~Hz})$.

2-Amino-3-methyl-pentanoic acid methyl ester-HCl: (15-HCl): Dissolved $5.0 \mathrm{~g} \mathrm{(38} \mathrm{mmol)}$<smiles>CCC(C)C(N)C(=O)OC</smiles>
of Isoleucine in $50 \mathrm{~mL}$ of methanol and cool to $0^{\circ} \mathrm{C}$. Added $95 \mathrm{mmol}$ $(11.35 \mathrm{~g} / 10.0 \mathrm{~mL})$ of thionyl chloride drop wise over a period of 5 minutes. The solution was refluxed for 4 hours until clear is clear solution. And the solvent was evaporated giving the crude methyl ester$\mathrm{HCl}$, which was triturated with ether at $0^{\circ} \mathrm{C}$. The resulting solid product was collected and the dried under high vacuum to yield $85 \%$ crude methyl ester $\mathrm{HCl}$. The crude material was recrystallized from $25 \mathrm{~mL}$ of hot methanol by slow addition of $100 \mathrm{~mL}$ ether followed by cooling at $0^{\circ} \mathrm{C}$. The crystals were collected, washed twice with $5: 1$ of ether: methanol solution and dried under high vacuum to obtained $6 \mathrm{~g}$ of pure product in $68 \% .{ }^{1} \mathrm{H} \mathrm{NMR}(200 \mathrm{MHz}$, 
$\left.\mathrm{CDCl}_{3}\right):{ }^{\delta} 8.95-8.75(\mathrm{br}-\mathrm{s}, 2 \mathrm{H}, \mathrm{NH}), 4.05(\mathrm{t}, 1 \mathrm{H}, J=3.8 \& 7.2 \mathrm{~Hz}), 3.80(\mathrm{~s}, 3 \mathrm{H}), 2.20-2.15(\mathrm{~m}$, $1 \mathrm{H}), 1.60-1.35(\mathrm{~m}, 2 \mathrm{H}), 1.10(\mathrm{~d}, 3 \mathrm{H}, J=7.0 \mathrm{~Hz}), 0.92(\mathrm{t}, 3 \mathrm{H}, J=7.2 \& 14.6 \mathrm{~Hz})$.

2-Amino-3-methyl-pentanoic acid methyl ester: (15): Dissolved $6 \mathrm{~g}$ of salt in $100 \mathrm{~mL}$ of<smiles>CCC(C)C(N)C(=O)OC</smiles>

1.0 M solution of sodium carbonate in a beaker. Stir the reaction mixture at room temperature for one hour. Extracted with DCM (50 $\mathrm{mL} X 2)$, washed the combine organic layer with water $(10 \mathrm{~mL})$, brine solution $(100 \mathrm{~mL})$, dried over $\mathrm{MgSO}_{4}$ and filtered. Concentrated under reduced pressure to obtain $4.3 \mathrm{~g}$ of product 15 as residual oil in $78 \%$ yield. ${ }^{1} \mathrm{H}$ NMR $\left(200 \mathrm{MHz}, \mathrm{CDCl}_{3}\right)$ : $\delta 3.78(\mathrm{~s}, 3 \mathrm{H}), 3.34(\mathrm{~d}$, $1 \mathrm{H}, J=4.8 \mathrm{~Hz}), 1.75(\mathrm{~m}, 1 \mathrm{H}), 1.45-1.35(\mathrm{~m}, 1 \mathrm{H}), 1.25-1.15(\mathrm{~m}, 1 \mathrm{H}), 0.98-0.78(\mathrm{~m}, 6 \mathrm{H})$.<smiles>CCC(C)C(Nc1ccc([N+](=O)[O-])cc1[N+](=O)[O-])C(=O)NC(C(=O)OC)C(C)CC</smiles>
methyl ester: (16): Dissolved $1.0 \mathrm{~g}$ of methyl ester 15 in dichloromethane $(10 \mathrm{~mL})$ under nitrogen atmosphere. Cool to $0^{\circ} \mathrm{C}$ and $2.0 \mathrm{~g}$ of acid chloride 14 solution (in dichloromethane, $10 \mathrm{~mL}$ ) was added drop wise over a

period of 5 minutes. Maintained at room temperature for $6 \mathrm{~h}$ and pour the reaction mass into beaker containing $50 \mathrm{~mL}$ of water. Extracted with dichloromethane $(100 \mathrm{~mL})$. Washed the organic layer with saturated $\mathrm{NaHCO}_{3}$ solution, brine solution, dried over $\mathrm{MgSO}_{4}$, and filtered. Concentration under reduced pressure and column chromatographic purification to obtain the $2.0 \mathrm{~g}$ of product 16 in $74.62 \%$ yield. ${ }^{1} \mathrm{H}$ NMR $\left(200 \mathrm{MHz}, \mathrm{CDCl}_{3}\right):{ }^{\delta} 9.17-9.15$ (dd, $1 \mathrm{H}, J=0.8$ \& $1.8 \mathrm{~Hz}), 8.84(\mathrm{~d}, 1 \mathrm{H}, \mathrm{NH}, J=6.2 \mathrm{~Hz}), 8.30-8.24(\mathrm{dd}, 1 \mathrm{H}, J=2.6 \& 7.0 \mathrm{~Hz}), 6.81(\mathrm{~d}, 1 \mathrm{H}, J=$ $8.4 \mathrm{~Hz}), 6.42(\mathrm{~d}, 1 \mathrm{H}, J=8.0 \mathrm{~Hz}), 4.61-4.55(\mathrm{dd}, 1 \mathrm{H}, J=4.2 \& 4.0 \mathrm{~Hz}), 4.03-4.00(\mathrm{t}, 1 \mathrm{H}, J=$ $5.6 \& 11.4 \mathrm{~Hz}), 3.71(\mathrm{~s}, 3 \mathrm{H}), 2.20-1.80(\mathrm{~m}, 1 \mathrm{H}), 1.80-1.60(\mathrm{~m}, 1 \mathrm{H}), 1.45-1.25(\mathrm{~m}, 1 \mathrm{H}), 1.05-$ $0.90(\mathrm{~m}, 6 \mathrm{H})$. Mass m/z: $424(\mathrm{M}+)$. 
<smiles>CCC(C)C(NC(=O)C(Nc1ccc([N+](=O)[O-])cc1[N+](=O)[O-])C(C)CC)C(=O)O</smiles>

(2b): Dissolved $1.0 \mathrm{~g}(2.3 \mathrm{mmol})$ of methyl ester $16(2.3 \mathrm{mmol})$ in THF: water $10 \mathrm{~mL}: 5 \mathrm{~mL}$. Added $280 \mathrm{mg}(12 \mathrm{mmol})$ of lithium hydroxide portion wise over a period of 10 minutes. Stirred at room temperature for 12 hours. Initially it was dark red which gradually turns to pale red (after 2 hours) and yellow (after 4 hours). Concentrated on rota evaporator under reduced pressure to remove the THF. Dissolved the residue in 15 $\mathrm{mL}$ of water and neutralized with conc. $\mathrm{HCl}(5 \mathrm{~mL})$ and filtered, washed the yellow solid with water $(10 \mathrm{~mL} \times 2)$ followed by hexane $(10 \mathrm{~mL} \times 2)$. Transferred the solid to single neck flask and add benzene $(10 \mathrm{~mL} \times 2)$, concentrated on rota evaporator under pressure to obtain 750 mg of yellow solid $\mathbf{2 b}$ in $78 \%$ yield. ${ }^{1} \mathrm{H}$ NMR $\left(200 \mathrm{MHz}, \mathrm{CDCl}_{3}\right): \quad{ }^{\delta} 9.14(\mathrm{~d}, 1 \mathrm{H}, J=2.4 \mathrm{~Hz})$, $8.81(\mathrm{~d}, 1 \mathrm{H}, \mathrm{NH}, J=5.4 \mathrm{~Hz}), 8.22(\mathrm{dd}, 1 \mathrm{H}, J=7.2), 6.86(\mathrm{~d}, 1 \mathrm{H}, J=8.4 \mathrm{~Hz}), 6.37(\mathrm{~d}, 1 \mathrm{H}, \mathrm{NH}$, $J=8.6 \mathrm{~Hz}), 4.61-4.56(\mathrm{dd}, 1 \mathrm{H}, J=4.2 \& 9.2 \mathrm{~Hz}), 4.07-4.05(\mathrm{t}, 1 \mathrm{H}, J=4.2 \& 9.2 \mathrm{~Hz}), 2.10-$ $2.05(\mathrm{~m}, 1 \mathrm{H}), 2.05-1.95(\mathrm{~m}, 1 \mathrm{H}), 1.90-1.65(\mathrm{~m}, 1 \mathrm{H}), 1.45-1.25(\mathrm{~m}, 2 \mathrm{H}), 1.15-0.95(\mathrm{~m}, 6 \mathrm{H}) .{ }^{13} \mathrm{C}$ NMR $\left(50 \mathrm{MHz}, \mathrm{CDCl}_{3}\right):{ }^{\delta} 175.7,170.3,147.8,137.4,131.6,130.6,124.0,115.2,63.5,56.5$, $37.8,37.2,28.8,25.2,24.9,15.8,15.5,11.4$. Mass m/z: $410(M+)$.

2-(2,4-Dinitro-phenylamino)-4-methyl-pentanoic acid: (17): Dissolved $10.0 \mathrm{~g}$ (76 mmol) of<smiles>CC(C)CC(Nc1c[12c]c([N+](=O)[O-])cc1[N+](=O)[O-])C(=O)O</smiles>
L-Leucine in $250 \mathrm{~mL}$ of $0.1 \mathrm{M}$ sodium bicarbonate solutions in a beaker. Add $76 \mathrm{~mol}(8.51 \mathrm{~g} / 5.73 \mathrm{~mL})$ of 2,4-dinitrofluorobenzene solution (in $30 \mathrm{~mL}$ of acetone) over a period of 5 minutes. Stirred for 4 hours at room temperature. Distilled to half of its volume to get residue and neutralize with 2.0 $\mathrm{M} \mathrm{HCl}(30 \mathrm{~mL})$ and filtered, washed the yellow solid with water $(10 \mathrm{~mL} \times 2)$ followed by hexane (10 $\mathrm{mL} X 2)$. Transferred the solid to single neck flask and add benzene (10 $\mathrm{mL} X 2)$, concentrated on rota evaporator under pressure to obtain $10.75 \mathrm{~g}$ of yellow solid $\mathbf{1 7}$ in $75 \%$ 
yield. Melting point is $100-101^{\circ} \mathrm{C} .{ }^{1} \mathrm{H}$ NMR $\left(200 \mathrm{MHz}, \mathrm{CDCl}_{3}\right):{ }^{\delta} 9.16-9.14(\mathrm{dd}, 1 \mathrm{H}, \mathrm{J}=2.6$ \& $1.4 \mathrm{~Hz}), 8.72(\mathrm{~d}, 1 \mathrm{H}, J=7.2 \mathrm{~Hz}), 8.32-8.26(\mathrm{dd}, 1 \mathrm{H}, J=1.8 \& 5.4 \mathrm{~Hz}), 6.86(\mathrm{~d}, 1 \mathrm{H}, J=9.6$ $\mathrm{Hz}), 4.40-4.29(\mathrm{q}, 1 \mathrm{H}, J=7.0 \& 7.4 \mathrm{~Hz}), 1.98-1.70(\mathrm{~m}, 3 \mathrm{H}), 1.06-0.96(\mathrm{dd}, 6 \mathrm{H}, J=6.0 \& 9.6$ Hz). Mass m/z: $297(M+)$.

2-(2,4-Dinitro-phenylamino)-4-methyl-pentanoyl chloride: (18): Suspended $10.0 \mathrm{~g} \mathrm{(33}$<smiles>CC(C)CC(Nc1ccc([N+](=O)[O-])cc1[N+](=O)[O-])C(=O)Cl</smiles>
mmol) of $\mathrm{N}$-(2,4-Dintrophenyl)-Leucine 17 in benzene $(100 \mathrm{~mL})$, Add $40 \mathrm{mmol}(5.12 \mathrm{~g} / 3.6 \mathrm{~mL})$ of oxalyl chloride drop wise over a period of 5 minutes under nitrogen atmosphere. Stir at room temperature for 2 hours. Concentrate on rota evaporator to get $10 \mathrm{~g}$ of reddish solid product 18 in $95 \%$ yield. ${ }^{1} \mathrm{H}$ NMR (200 MHz, $\left.\mathrm{CDCl}_{3}\right):{ }^{\delta} 9.19(\mathrm{~d}, 1 \mathrm{H}, J=2.8 \mathrm{~Hz}), 8.69(\mathrm{~d}, 1 \mathrm{H}, J=7.8 \mathrm{~Hz}), 8.38-8.32$ (dd, $1 \mathrm{H}, J=2.6 \& 7.6 \mathrm{~Hz}), 6.82(\mathrm{~d}, 1 \mathrm{H}, J=9.6 \mathrm{~Hz}), 4.57-4.46(\mathrm{~m}, 1 \mathrm{H}), 2.05-1.70(\mathrm{~m}, 3 \mathrm{H}), 1.10-$ $0.99(\mathrm{dd}, 6 \mathrm{H}, J=7.2 \& 4.8 \mathrm{~Hz})$.

2-Amino-4-methyl-pentanoic acid methyl ester (19): Dissolved $20.0 \mathrm{~g}$ (152 mmol) of L-<smiles>COC(=O)C([18OH])CC(C)C</smiles>

$19 \mathrm{O}$

Leucine in $100 \mathrm{~mL}$ of methanol and cool to $0^{\circ} \mathrm{C}$. Added $182 \mathrm{mmol}(21.76$ $\mathrm{g} / 15 \mathrm{~mL}$ ) of thionyl chloride drop wise over a period of 15 minutes.

Similar to compound 15. After workup obtained $25.0 \mathrm{~g}$ of salt 19 in $90 \%$ yield.

2-[2-(2,4-Dinitro-phenylamino)-4-methyl-pentanoylamino]-4-methyl-pentanoic

acid<smiles>COC(=O)C(CC(C)C)NC(=O)C(CC(C)C)Nc1ccc([N+](=O)[O-])cc1[N+](=O)[O-]</smiles>
methyl ester: (20): Suspend $6.9 \mathrm{~g}(37.9 \mathrm{mmol})$ of methyl ester $\mathrm{HCl}$ salt 19 in dichloromethane $(100 \mathrm{~mL})$ under nitrogen atmosphere. Cool to $0^{\circ} \mathrm{C}$ and add $5.3 \mathrm{~g}(63.0$ $\mathrm{mmol}$ ) of sodium carbonate at $0^{\circ} \mathrm{C}$ and stir for 1 hour. Drop wise addition of $10.0 \mathrm{~g}(31.5 \mathrm{mmol})$ of acid chloride 18 solution (10 mL of dichloromethane,) over a period of 15 minutes. Maintained at room temperature for $6 \mathrm{~h}$ and pour the reaction 
mass into beaker containing $250 \mathrm{~mL}$ of water. Extracted with dichloromethane $(50 \mathrm{~mL} \times 2)$. Washed the combined organic layer with saturated $\mathrm{NaHCO}_{3}$ solution, brine solution, dried over $\mathrm{MgSO}_{4}$, and filtered. Concentrated under reduced pressure and purified by column chromatography to obtain the $10.0 \mathrm{~g}$ of product 20 in $75 \%$ yield. ${ }^{1} \mathrm{H}$ NMR $\left(200 \mathrm{MHz}, \mathrm{CDCl}_{3}\right)$ : $\delta 9.17(\mathrm{~d}, 1 \mathrm{H}, J=2.8 \mathrm{~Hz}), 8.63(\mathrm{~d}, 1 \mathrm{H}, \mathrm{NH}, J=5.6 \mathrm{~Hz}), 8.33-8.27(\mathrm{dd}, 1 \mathrm{H}, J=2.6 \& 7.2 \mathrm{~Hz})$, $6.89(\mathrm{~d}, 1 \mathrm{H}, J=9.6 \mathrm{~Hz}), 6.32(\mathrm{~d}, 1 \mathrm{H}, \mathrm{NH}, J=8.4 \mathrm{~Hz}), 4.65-4.55(\mathrm{~m}, 1 \mathrm{H}), 4.15-4.00(\mathrm{~m}, 1 \mathrm{H})$, $3.65(\mathrm{~s}, 3 \mathrm{H}), 1.95-1.70(\mathrm{~m}, 3 \mathrm{H}), 1.06-1.03(\mathrm{~d}, 3 \mathrm{H}, \mathrm{J}=6.0 \mathrm{~Hz}), 0.96-0.91(\mathrm{~m}, 9 \mathrm{H})$. Mass $\mathrm{m} / \mathrm{z}$ : $424(\mathrm{M}+)$.

\section{2-[2-(2,4-Dinitro-phenylamino)-4-methyl-pentanoylamino]-4-methyl-pentanoic}

acid:<smiles>CC(C)CC(NC(=O)C(CC(C)C)Nc1ccc([N+](=O)[O-])cc1[N+](=O)[O-])C(=O)O</smiles>

gradually turns to pale red (after 2 hours) and yellow (after 4 hours). Concentrated on rota evaporator under reduced pressure to remove the THF. Dissolved the residue in $15 \mathrm{~mL}$ of water and neutralize with conc. $\mathrm{HCl}(5 \mathrm{~mL})$ and filtered, washed the yellow solid with water (10 $\mathrm{mL} X 2)$ followed by hexane $(10 \mathrm{~mL} \times 2)$. Transfer the solid to single neck flask and added benzene (10 $\mathrm{mL} X 2)$, concentrated on rota evaporator under pressure to obtain $1.45 \mathrm{~g}$ of yellow solid $2 \mathrm{c}$ in $75 \%$ yield. ${ }^{1} \mathrm{H}$ NMR $\left(200 \mathrm{MHz}\right.$, acetone- $\left.\mathrm{d}_{6}\right):{ }^{\delta} 9.09(\mathrm{~d}, 1 \mathrm{H}, \mathrm{J}=2.6 \mathrm{~Hz})$, $8.60(\mathrm{~d}, 1 \mathrm{H}, \mathrm{NH}, J=5.4 \mathrm{~Hz}), 8.24-8.19(\mathrm{dd}, 1 \mathrm{H}, J=2.6 \& 7.0 \mathrm{~Hz}), 6.91(\mathrm{~d}, 1 \mathrm{H}, J=9.6 \mathrm{~Hz})$, 6.49 (br-s, 1H, NH), 4.65-4.56 (dis-d, $1 \mathrm{H}, J=8.8 \& 17.6 \mathrm{~Hz}$ ), 4.16-4.07 (d, $1 \mathrm{H}, J=6.0 \mathrm{~Hz}$ ), 1.98-1.70 (m, 4H), 1.06-1.03 (d, 3H, J=5.8 Hz), 0.96-0.91 (m, 9H). Mass m/z: $410(\mathrm{M}+)$.

2-(2,4-Dinitro-phenylamino)-3-phenyl-propionic acid: (21): Dissolved $5.0 \mathrm{~g} \mathrm{(30} \mathrm{mmol)} \mathrm{of}$ Phenyl alanine in $100 \mathrm{~mL}$ of $0.1 \mathrm{M}$ sodium bicarbonate solution in a<smiles>CCCC(Nc1ccc([N+](=O)[O-])cc1[N+](=O)[O-])C(Cc1ccccc1)C(=O)O</smiles> 
beaker. Add $18 \mathrm{~mol}(3.3 \mathrm{~g} / 2.2 \mathrm{~mL}$ ) of 2,4-dinitrofluorobenzene solution (in $10 \mathrm{~mL}$ of acetone) over a period of 5 minutes. Stir for 4 hours at room temperature. Distilled to half of its volume to get residue and neutralize with $2.0 \mathrm{M} \mathrm{HCl}(30 \mathrm{~mL})$ and filtered, washed the yellow solid with water $(10 \mathrm{~mL} \times 2)$ followed by hexane ( $10 \mathrm{~mL} \times 2)$. Transferred the solid to single neck flask and add benzene (10 $\mathrm{mL} X 2)$, concentrated on rota evaporator under pressure to obtain $7.5 \mathrm{~g}$ of yellow solid $\mathbf{2 1}$ in $75 \%$ yield. The product is soluble in methanol, ethanol, ethyl acetate, dichloromethane, chloroform and hot benzene. ${ }^{1} \mathrm{H}$ NMR $(200 \mathrm{MHz}$, Acetone d6): $\left.{ }^{\delta} 9.00(\mathrm{~d}, 1 \mathrm{H}), J=2.8 \mathrm{~Hz}\right), 8.91(\mathrm{~d}, 1 \mathrm{H}, \mathrm{NH}, J=7.2 \mathrm{~Hz}), 8.31-8.26(\mathrm{dd}, 1 \mathrm{H}, J=2.8 \& 6.8$ $\mathrm{Hz}), 7.35-7.27(\mathrm{~m}, 6 \mathrm{H}), 5.10-5.01(\mathrm{dd}, 1 \mathrm{H}, \mathrm{J}=5.8 \& 7.6 \mathrm{~Hz}), 3.48-3.24(\mathrm{~m}, 2 \mathrm{H}) .{ }^{1} \mathrm{H}$ NMR $(200$ $\mathrm{MHz}, \mathrm{CDCl}_{3}$ one drop of acetone $\left.\mathrm{d}_{6}\right):{ }^{\delta} 8.88(\mathrm{~d}, 1 \mathrm{H}, J=1.4 \mathrm{~Hz}), 8.70(\mathrm{~d}, 1 \mathrm{H}, \mathrm{NH}, J=7.6 \mathrm{~Hz})$, 8.02-7.96 (dd, $1 \mathrm{H}, J=2.4 \& 7.2 \mathrm{~Hz}), 7.09-7.00(\mathrm{~m}, 5 \mathrm{H}), 6.62(\mathrm{~d}, 1 \mathrm{H}, J=8.4 \mathrm{~Hz}), 4.55-4.45$ $(\mathrm{m}, 1 \mathrm{H}), 3.30-3.20(\mathrm{dd}, 1 \mathrm{H}, J=5.0 \& 9.0 \mathrm{~Hz}), 3.13-3.03(\mathrm{dd}, 1 \mathrm{H}, J=7.0 \& 6.8 \mathrm{~Hz})$. Mass $\mathrm{m} / \mathrm{z}$ : $331(\mathrm{M}+)$.

2-(2,4-Dinitro-phenylamino)-3-phenyl-propionyl chloride: (22): Suspended 5.0 g (15<smiles>O=C(Cl)C(Cc1ccccc1)Nc1ccc([N+](=O)[O-])cc1[N+](=O)[O-]</smiles>
$\mathrm{mmol})$ of $\mathrm{N}$ - (2,4-Dintrophenyl)-Phenylalanine 21 in benzene $(50 \mathrm{~mL})$, Add $18 \mathrm{mmol}(2.3 \mathrm{~g} / 2.0 \mathrm{~mL})$ of oxalyl chloride drop wise over a period of 5 minutes under nitrogen atmosphere. Stirred at room temperature for 2 hours. Concentrated on rota evaporator to get $4.75 \mathrm{~g}$ of product 22 in $90 \%$ yield. ${ }^{1} \mathrm{H}$ NMR $\left(200 \mathrm{MHz}, \mathrm{CDCl}_{3}\right):{ }^{\delta} 9.09(\mathrm{~d}, 1 \mathrm{H}, J=2.8 \mathrm{~Hz}), 8.84(\mathrm{~d}, 1 \mathrm{H}, \mathrm{NH}, J=7.2 \mathrm{~Hz})$, 8.30-8.24 (dd, $1 \mathrm{H}, J=2.6 \& 6.8 \mathrm{~Hz}), 7.40-7.20(\mathrm{~m}, 5 \mathrm{H}), 6.75(\mathrm{~d}, 1 \mathrm{H}, J=8.4 \mathrm{~Hz}), 4.89-4.81$ (m, 1H), 3.60-3.40 (m, 2H).

2-Amino-3-phenyl-propionic acid methyl ester- $\mathrm{HCl}$ (23): Dissolved $5.0 \mathrm{~g} \mathrm{(30} \mathrm{mmol)} \mathrm{of} \mathrm{L-}$ $\mathrm{ClH} \mathrm{H}_{2} \overbrace{\mathrm{O}}^{\mathrm{OCCH}_{3}}$ Phenylalanine in $100 \mathrm{~mL}$ of methanol and cool to $0^{\circ} \mathrm{C}$. Added $36 \mathrm{mmol}$ $(4.32 \mathrm{~g} / 4.0 \mathrm{~mL})$ of thionyl chloride drop wise over a period of 5 minutes. Page 16 of 23 
Similar to compound 15. After workup obtained $5.8 \mathrm{~g}$ of salt 23 in $90 \%$ yield.

2-[2-(2,4-Dinitro-phenylamino)-3-phenyl-propionylamino]-3-phenyl-propionic

acid<smiles>COC(=O)C(Cc1ccccc1)NC(=O)C(Cc1ccccc1)Nc1ccc([N+](=O)[O-])cc1[N+](=O)[O-]</smiles>
methyl ester: (24): Suspended $3.5 \mathrm{~g}(16.3 \mathrm{mmol})$ of methyl ester $\mathrm{HCl}$ salt 23 in dichloromethane $(50 \mathrm{~mL})$ under nitrogen atmosphere. Cool to $0^{\circ} \mathrm{C}$ and add $2.88 \mathrm{~g}(27 \mathrm{mmol})$ of sodium carbonate at $0^{\circ} \mathrm{C}$ and stir for 1 hour. Drop wise

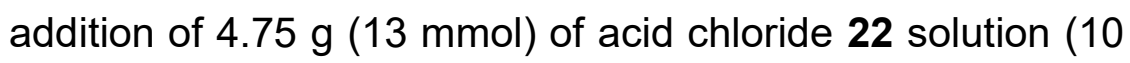
$\mathrm{mL}$ of dichloromethane,) over a period of 15 minutes. Maintained at room temperature for 6 hours and pour the reaction mass into beaker containing $250 \mathrm{~mL}$ of water. Extracted with dichloromethane $(50 \mathrm{~mL} \times 2)$. Washed the combined organic layer with saturated $\mathrm{NaHCO}_{3}$ solution, brine solution, dried over $\mathrm{MgSO}_{4}$, and filtered. Concentrated under reduced pressure and purified by column chromatography to obtain the $4.75 \mathrm{~g}$ of product 24 in $71 \%$ yield. ${ }^{1} \mathrm{H}$ NMR $\left(200 \mathrm{MHz}, \mathrm{CDCl}_{3}\right):{ }^{\delta} 9.09(\mathrm{~d}, 1 \mathrm{H}, J=2.8 \mathrm{~Hz}), 8.74(\mathrm{~d}, 1 \mathrm{H}, \mathrm{NH}, J=6.8 \mathrm{~Hz}), 8.25-8.20$ (dd, $1 \mathrm{H}, \mathrm{NH}, J=2.8 \& 6.8 \mathrm{~Hz}), 7.41-7.20(\mathrm{~m}, 9 \mathrm{H}), 6.95-6.90(\mathrm{~m}, 1 \mathrm{H}), 6.77(\mathrm{~d}, 1 \mathrm{H}, J=8.4 \mathrm{~Hz})$, $6.42(\mathrm{~d}, 1 \mathrm{H}, J=8.0 \mathrm{~Hz}), 4.91-4.86(\mathrm{q}, 1 \mathrm{H}, J=2.2 \& 3.6 \mathrm{~Hz}), 4.35-4.30(\mathrm{q}, 1 \mathrm{H}, J=1.8 \& 5.6$ $\mathrm{Hz}), 3.86$ (s, 3H), 3.41-3.20 (m, 4H). ${ }^{1} \mathrm{H}$ NMR $\left(200 \mathrm{MHz}\right.$, acetone- $\left.\mathrm{d}_{6}\right):{ }^{\delta} 8.93(\mathrm{~d}, 1 \mathrm{H}, J=2.8$ $\mathrm{Hz}), 8.17-8.11(\mathrm{dd}, 1 \mathrm{H}, J=2.6 \& 7.0 \mathrm{~Hz}), 7.38-7.25(\mathrm{~m}, 10 \mathrm{H}), 6.87(\mathrm{~d}, 1 \mathrm{H}, J=9.6 \mathrm{~Hz}) 4.84-$ $4.75(\mathrm{~m}, 2 \mathrm{H}), 3.66(\mathrm{~s}, 3 \mathrm{H}), 3.66-2.92(\mathrm{~m}, 4 \mathrm{H})$. Mass m/z: $492(\mathrm{M}+)$.

2-[2-(2,4-Dinitro-phenylamino)-3-phenyl-propionylamino]-3-phenyl-propionic acid: (2d):<smiles>O=C(O)C(Cc1ccccc1)NC(=O)C(Cc1ccccc1)Nc1ccc([N+](=O)[O-])cc1[N+](=O)[O-]</smiles>

Dissolved $1.0 \mathrm{~g} \mathrm{(2} \mathrm{mmol)} \mathrm{of} \mathrm{methyl} \mathrm{ester} 24 \mathrm{in} \mathrm{THF:} \mathrm{water} 10$ $\mathrm{mL}: 5 \mathrm{~mL}$. Add $240 \mathrm{mg}(10 \mathrm{mmol})$ of lithium hydroxide portion wise over a period of 10 minutes. Stirred at room temperature for 4 hours. Initially it was dark red which gradually turns to 
pale red (after 2 hours) and yellow (after 4 hours). Concentrated on rota evaporator under reduced pressure to remove the THF. Dissolved the residue in $15 \mathrm{~mL}$ of water and neutralize with conc. $\mathrm{HCl}(5 \mathrm{~mL})$ and filtered, washed the yellow solid with water $(10 \mathrm{~mL} X 2)$ followed by hexane $(10 \mathrm{~mL} X 2)$. Transferred the solid to single neck flask and add benzene $(10 \mathrm{~mL} X$ 2), concentrated on rota evaporator under pressure to obtain $0.69 \mathrm{~g}$ of yellow solid $\mathbf{2 d}$ in $71 \%$ yield. ${ }^{1} \mathrm{H}$ NMR $\left(200 \mathrm{MHz}\right.$, acetone- $\left.\mathrm{d}_{6}\right):{ }^{\delta} 8.90(\mathrm{~d}, 1 \mathrm{H}, J=2.6 \mathrm{~Hz}), 8.86(\mathrm{~d}, 1 \mathrm{H}, \mathrm{NH}, J=7.2$ $\mathrm{Hz}), 8.12-8.06(\mathrm{dd}, 1 \mathrm{H}, J=2.2 \& 7.4 \mathrm{~Hz}), 7.96(\mathrm{~d}, 1 \mathrm{H}, J=8.2 \mathrm{~Hz}), 7.18-7.08(\mathrm{~m}, 10 \mathrm{H})$, 6.81(d, $1 \mathrm{H}, J=9.6 \mathrm{~Hz}), 4.89-4.74(\mathrm{~m}, 2 \mathrm{H}), 3.42-2.98(\mathrm{~m}, 4 \mathrm{H})$. Mass m/z: $478(\mathrm{M}+)$.

5-Nitro-[1,10]phenanthroline (25): Charged $30 \mathrm{~g}$ (166 mmol) of 1,10-Phenantranene in a $N_{25}$ R.B. and cool to $0^{\circ} \mathrm{C}$. Add $30 \%$ fuming sulfuric acid, over a period of 1 hour while maintaining the temperature. Drop wise addition of $90 \mathrm{~mL}$ of Conc. Nitric acid over a period of 1 hour, while maintaining the temperature. Removed cooling and stir at RT for 30 minutes. Heated at $130-140^{\circ} \mathrm{C}$ for 4 hours. Cool to RT. Poured the reaction mixture into $2 \mathrm{~L}$ beaker containing $1 \mathrm{~kg}$ of crushed ice, neutralized with $\mathrm{NaOH}$ pellets $(150 \mathrm{~g})$ to adjust the $\mathrm{pH}=8$, ppt is formed, filtered, and washed the solid with water $(1 \mathrm{~L})$. Suspended the solid in chloroform $(250 \mathrm{~mL})$ and filtered to get $12 \mathrm{~g}$ of pure product 25 obtained in $32 \%$ yield. ${ }^{1} \mathrm{H}$ NMR $\left(200 \mathrm{MHz}, \mathrm{CDCl}_{3}\right):{ }^{\delta} 9.37$ (dd, $2 \mathrm{H}, J=2.8 \mathrm{~Hz} \& 4.4 \mathrm{~Hz}), 9.02(\mathrm{dd}, 1 \mathrm{H}, J=1.6 \& 7.0 \mathrm{~Hz}), 8.70(\mathrm{~s}, 1 \mathrm{H}), 8.42(\mathrm{dd}, 1 \mathrm{H}, J=1.8 \&$ 6.4 Hz), 7.86-7.75 (m, 2H). ${ }^{1} \mathrm{H}$ NMR (200 MHz, acetone-d6): $\delta$ 9.31-9.24 (m, 2H), 8.90 (m, 2H), $8.80(\mathrm{dd}, 1 \mathrm{H}, J=2.0 \& 5.2 \mathrm{~Hz}), 7.98-7.90$ (m, 2H). Mass: 225, GC-MS: 225, 5,6DINITRO PHENANTHRANE (impurities). ${ }^{1} \mathrm{H}$ NMR $\left(200 \mathrm{MHz}, \mathrm{CDCl}_{3}\right):{ }^{\delta} 8.80$ (dd, $2 \mathrm{H}, J=1.2$ $\mathrm{Hz} \& 3.0 \mathrm{~Hz}), 8.02(\mathrm{dd}, 1 \mathrm{H}, J=1.0 \& 1.6 \mathrm{~Hz}), 7.95(\mathrm{~s}, 2 \mathrm{H}),(\mathrm{dd}, 1 \mathrm{H}, J=4.0 \& 8.0 \mathrm{~Hz})$. PHENSM: NMR ${ }^{1} \mathrm{H}$ NMR $(200 \mathrm{MHz}$, acetone-d $)$ ): ${ }^{\delta} 9.13(\mathrm{dd}, 2 \mathrm{H}, J=1.8 \mathrm{~Hz} \& 2.6 \mathrm{~Hz}), 8.46$ (dd, $2 \mathrm{H}, J=1.8 \& 13.2 \mathrm{~Hz}), 8.70(\mathrm{~s}, 1 \mathrm{H}), 8.42(\mathrm{dd}, 1 \mathrm{H}, J=1.8 \& 6.4 \mathrm{~Hz}), 7.86-7.75(\mathrm{~m}, 2 \mathrm{H})$. 
5-Amine[1,10]Phenanthroline (26): METHOD-A: Palladium charcoal slurry is prepared by<smiles>Nc1cc2cccnc2c2cccnc12</smiles>
adding $250 \mathrm{mg}$ of palladium cautiously with spatula into a conical flask containing $100 \mathrm{~mL}$ of methanol. Dissolved $5 \mathrm{~g}$ (22.2 mol) of 5-Nitro-1,10Phenantranene 25 in $50 \mathrm{~mL}$ of methanol in a single neck R.B. flask. Transferred the palladium slurry to R.B. flask containing the compound 25 solution. Washed the palladium slurry conical with additional $50 \mathrm{~mL}$ of methanol and transferred to R.B. flask. kept under Hydrogen atmosphere and stirred in hydrogen atmosphere until sm disappeared. (18 hours). Filtered through silica gel; wash the palladium with methanol and DCM. Concentrated the filtrate to get gummy material. Hexane was added and scratches with glass rod to form solid, filtered to obtained $4.3 \mathrm{~g}$ of product $\mathbf{2 6}$ in $98 \%$ yield. Rf value of $\mathrm{sm} 0.6 \mathrm{sm}$, product 0.4 , polarity 9.5:0.5 Methanol: aqueous ammonia solution. ${ }^{1} \mathrm{H}$ NMR $\left(200 \mathrm{MHz}, \mathrm{CDCl}_{3}\right):{ }^{\delta} 9.21(\mathrm{~d}, 1 \mathrm{H}, J=4.0 \mathrm{~Hz}), 8.95(\mathrm{~d}, 1 \mathrm{H}, J=4.0 \mathrm{~Hz}), 8.30$ $(\mathrm{d}, 1 \mathrm{H}, J=8.0 \mathrm{~Hz}), 8.00(\mathrm{~d}, 1 \mathrm{H}, J=8.0 \mathrm{~Hz}), 7.68(\mathrm{dd}, 1 \mathrm{H}, J=4.0 \& 8.0 \mathrm{~Hz}), 7.50(\mathrm{dd}, 1 \mathrm{H}, J=$ $4.0 \& 8.0 \mathrm{~Hz}), 6.95$ (s, 1H). ${ }^{1} \mathrm{H}$ NMR $\left(200 \mathrm{MHz}, \mathrm{DMSO}-\mathrm{d}_{6}\right):{ }^{\delta} 9.05(\mathrm{~d}, 1 \mathrm{H}, J=4.0 \mathrm{~Hz}), 8.66$ (m, 2H), $8.01(\mathrm{~d}, 1 \mathrm{H}, J=8.0 \mathrm{~Hz}), 7.71(\mathrm{dd}, 1 \mathrm{H}, J=4.0 \& 8.0 \mathrm{~Hz}), 7.46(\mathrm{dd}, 1 \mathrm{H}, J=4.0 \& 8.0$ $\mathrm{Hz}), 6.86(\mathrm{~s}, 1 \mathrm{H})$. Mass m/z: $195(\mathrm{M}+)$.

METHOD-B Dissolved $6.2 \mathrm{~g},(27.5 \mathrm{mmol}, 3.1 \mathrm{eq})$ stannous chloride dihydrate in $200 \mathrm{~mL}$ of ethanol in a single neck R.B. Added $2.0 \mathrm{~g}(8.89 \mathrm{mmol})$ of 5-Nitro-1,10-Phenantranene 25 heated at reflux for 8 hours. Removed solvent on rota evaporator to get residue. Cool to $0^{\circ} \mathrm{C}$, added slowly $1.0 \mathrm{M} \mathrm{NaOH}$ solution until $\mathrm{pH}=13$, ppt is formed. Filtered and washed with water. Transferred the solid into R.B. flask and added toluene $(10 \mathrm{ml} \times 2)$. Concentrated on rota evaporator to get the $0.9 \mathrm{~g}$ of product $\mathbf{2 6}$ in $51 \%$ yield. 
Ruthenium, bis(2,2'-bipyridine-kN1,kN1')dichloro (27): To a solution of $2.5 \mathrm{~g}$ (9.5<smiles></smiles>
$\mathrm{mmol}, 1.0 \mathrm{eq})$ of $\mathrm{RuCl}_{3} .3 \mathrm{H}_{2} \mathrm{O}$ and $2.75 \mathrm{~g}(61 \mathrm{mmol}, 6.4 \mathrm{eq})$ of $\mathrm{LiCl}$ in $25 \mathrm{ml}$ DMF was added $2.94 \mathrm{~g} \mathrm{(19} \mathrm{mmol,} 2.0 \mathrm{eq})$ bipyridine at room temperature. Heated at reflux for 45 minutes, while continuously check the tlc for emission under uv lamp. Cool to RT. Poured into $100 \mathrm{~mL}$ of acetone. After cooling in freezer for $24 \mathrm{~h}$, ppt is formed. Filtered and washed with water and acetone until pale color appeared. After 2 hours dry in vacuum, obtained $1.9 \mathrm{~g}$ of product 27 in $40 \%$ yield. Melting Point $=196-198^{\circ} \mathrm{C}$. Mass $(\mathrm{m} / \mathrm{z}): 484(\mathrm{M}+)$.

Ruthenium, bis(2,2'-bipyridine-kN1,kN1')[carbonato(2-)-kO,kO']-, (OC-6-22) (28): charged

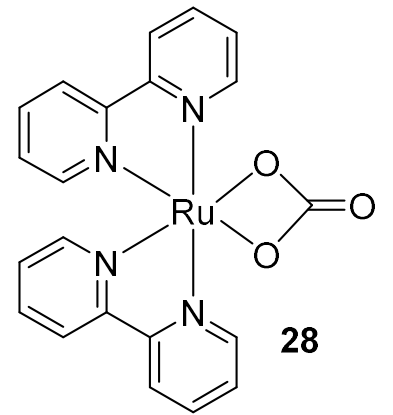

$2.0 \mathrm{~g}(4.13 \mathrm{mmol})$ of compound $27 \mathrm{in} 50 \mathrm{ml}$ of water, heated at reflux under argon atmosphere for 15 minutes. Added $6.6 \mathrm{~g}(6.3 \mathrm{mmol})$ of sodium carbonate and heated at reflux for 45 minutes. Cool to room temperature and filtered, washed the solid with water and dry in vacuum for 2 hours to obtained $1.3 \mathrm{~g}$ of product 28 in $67 \%$ yield. Mass: $474(\mathrm{M}+)$.

Ruthenium (2+), bis(2,2'-bipyridine-kN1,kN1')(1,10-phenanthrolin-5-amine-kN1,kN10)-, (OC-6-31)-, Perchlorate (3): To a $1.0 \mathrm{~g}(2.1 \mathrm{mmol})$ of

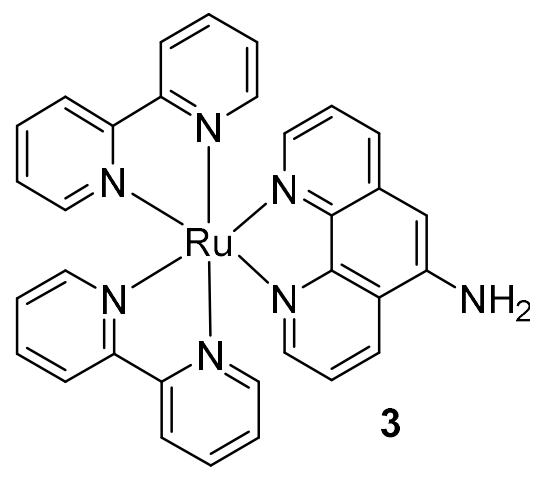
Ruthenium bipyridine carbonate, $\mathbf{2 8}$ in a R.B. flask and added $412 \mathrm{mg}(2.1 \mathrm{mmol})$ of 5-Amino, 1,10-phenantroline, 26 and 10 $\mathrm{ml}$ of water $(10 \mathrm{~mL})$. Heated at $75^{\circ} \mathrm{C}$ for 45 minutes under nitrogen atmosphere. Observed the emission in UV lamp, cool to room temperature, poured into beaker containing $15 \mathrm{~mL}$ of 
water. Added $1 \mathrm{~g}$ of sodium perchlorate solid while stirring, ppt formed. Filtered and washed with water, ether, and dry to get 1.7 of product 3 in 90\% yield. Mass: $608(\mathrm{M}+), 709\left(\mathrm{M}+\mathrm{ClO}_{4}\right)$, $829\left(\mathrm{M}+\left[\mathrm{ClO}_{4}\right]_{2}+\mathrm{H}_{2} \mathrm{O}\right)$.

\section{- Acknowledgement:}

G.S.R thankful to National Science Council of Taiwan, (ROC) for financial support in the form of Post-Doctoral Fellowship from February 2000 to July 2003. G.S.R is thankful to Chang I Jy at National Taiwan Normal University, Taipei, Taiwan, for conducting the experiments and collection and processing of the spectral data are gratefully acknowledged.

\section{- Competing interests:}

There is no Competing Interests pending.

\section{Reference:}

1 Gust, D., Moore, T. A. \& Moore, A. L. Molecular mimicry of photosynthetic energy and electron transfer. Accounts of Chemical Research 26, 198-205, doi:10.1021/ar00028a010 (1993).

2 Karidi, K. et al. Synthesis, Characterization, and DNA-Binding Studies of Nitro(oligopyridine)ruthenium(II) Complexes. Inorganic Chemistry 45, 10282-10292, doi:10.1021/ic0608039 (2006).

3 de Carvalho, I. M. M., Diógenes, I. C. N., Moreira, Í. d. S. \& Gehlen, M. H. Effect of the pH in the luminescence of ruthenium tris-bipyridine derivatives. Journal of Photochemistry and $\begin{array}{llll}\text { Photobiology } & \text { A: } & \text { 171, Chemistry }\end{array}$ doi:https://doi.org/10.1016/j.jphotochem.2004.09.010 (2005).

4 Geisser, B., Ponce, A. \& Alsfasser, R. pH-Dependent Excited-State Dynamics of [Ru(bpy)3]2+Modified Amino Acids: Effects of an Amide Linkage and Remote Functional Groups. Inorganic Chemistry 38, 2030-2037, doi:10.1021/ic980896x (1999).

5 Winkler, J. R., Malmström, B. G. \& Gray, H. B. Rapid electron injection into multisite metalloproteins: intramolecular electron transfer in cytochrome oxidase. Biophysical Chemistry 54, 199-209, doi:https://doi.org/10.1016/0301-4622(94)00156-E (1995).

6 Lee, J. C., Chang, I. J., Gray, H. B. \& Winkler, J. R. The Cytochrome c Folding Landscape Revealed by Electron-transfer Kinetics. J. Mol. Biol. 320, 159-164, doi:10.1016/S00222836(02)00466-7 (2002).

7 Nair, R. B., Cullum, B. M. \& Murphy, C. J. Optical Properties of $[R u(p h e n) 2 d p p z] 2+$ as a Function of Nonaqueous Environment. Inorganic Chemistry 36, 962-965, doi:10.1021/ic960862u (1997).

8 Sun, L. et al. Hydrogen-Bond Promoted Intramolecular Electron Transfer to Photogenerated $\mathrm{Ru}(\mathrm{III})$ : A Functional Mimic of TyrosineZ and Histidine 190 in Photosystem II. Journal of the 
American Chemical Society 121, 6834-6842, doi:10.1021/ja984048c (1999).

9 Fan, B. et al. Synthesis and Physical Characterization of Novel Heme-Based Model Systems for Photoinitiated Electron Transfer. 1. Complexation of a RuProHis Bifunctional Peptide and Microperoxidase-11. Inorganic Chemistry 36, 3839-3846, doi:10.1021/ic9700415 (1997).

Su, C.-H., Lin, R.-J. \& Chang, I. J. Y. Photoinduced electron transfer of microperoxidase-8. J. Photosci. 6, 129-133 (1999).

11 Reddy, G. S., Chen, H.-Y. \& Chang, I. J. Cysteine-Specific Blue Fluorescence Probe. Journal of the Chinese Chemical Society 53, 1303-1308, doi:10.1002/jccs.200600174 (2006).

12 Reddy Gondi, S. \& Son, D. Y. Cholane Derivatives with Potential Ligating Groups at the 3- and 24-Positions. Synthetic Communications 36, 1317-1331, doi:10.1080/00397910500521803 (2006).

13 Lizzul-Jurse, A. et al. Readily functionalizable phosphonium-tagged fluorescent coumarins for enhanced detection of conjugates by mass spectrometry. Org. Biomol. Chem. 14, 7777-7791, doi:10.1039/C6OB01080F (2016).

Loudfoot, J. H. \& Kruger, J. E. DINITROPHENYL PEPTIDES: I. PREPARATION AND PROPERTIES OF SOME DINITROPHENYL GLYCYL DIPEPTIDES. Canadian Journal of Chemistry 41, 2462-2463, doi:10.1139/v63-362 (1963).

15 Coban, G., Kose, F. A., Kirmizibayrak, P. B. \& Pabuccuoglu, V. Synthesis, biological activity screening and molecular modeling study of acylaminoacetamide derivatives. Med. Chem. Res. 24, 3710-3729, doi:10.1007/s00044-015-1419-4 (2015).

16 Kader, A. T. \& Stirling, C. J. M. 42. Elimination-addition. Part III. New procedures for the protection of amino-groups. Journal of the Chemical Society (Resumed), 258-266, doi:10.1039/JR9640000258 (1964).

17 Cho, H.-J. \& Um, I.-H. The $\alpha$-effect in SNAr reaction of 1-fluoro-2,4-dinitrobenzene with hydrazine: ground-state destabilization versus transition-state stabilization. Bull. Korean Chem. Soc. 35, 2371-2374, doi:10.5012/bkcs.2014.35.8.2371 (2014).

18 Schröder, E. \& Lübke, K. Über Peptidsynthesen. C-terminale Teilsequenzen des Eledoisins und eledoisinanaloger Verbindungen. Experientia 20, 19-21, doi:10.1007/BF02146018 (1964). Billman, J. H. \& Parker, E. E. Amino Acids. I. Glycine. Journal of the American Chemical Society 65, 761-762, doi:10.1021/ja01245a008 (1943).

20 Jackson, R. F. W., Wishart, N., Wood, A., James, K. \& Wythes, M. J. Preparation of enantiomerically pure protected 4-oxo .alpha.-amino acids and 3-aryl .alpha.-amino acids from serine. The Journal of Organic Chemistry 57, 3397-3404, doi:10.1021/jo00038a030 (1992).

21 Maclaren, B. J. P-Methoxybenzyl esters of amino acids-their preparation and use in peptide synthesis. Australian Journal of Chemistry 24, 1695-1702 (1971).

22 Schkeryantz, J. M., Woo, J. C. G., Siliphaivanh, P., Depew, K. M. \& Danishefsky, S. J. Total Synthesis of Gypsetin, Deoxybrevianamide E, Brevianamide E, and Tryprostatin B: Novel Constructions of 2,3-Disubstituted Indoles. Journal of the American Chemical Society 121, 11964-11975, doi:10.1021/ja9925249 (1999).

23 Rao, K. R. \& Sober, H. A. Preparation and Properties of 2,4-Dinitrophenyl-L-amino Acids. Journal of the American Chemical Society 76, 1328-1331, doi:10.1021/ja01634a041 (1954).

24 Koshizuka, M., Makino, K. \& Shimada, N. Diboronic acid anhydride-catalyzed direct peptide bond formation enabled by hydroxy-directed dehydrative condensation. Org. Lett. 22, 86588664, doi:10.1021/acs.orglett.0c03252 (2020).

25 Devarayan, K., Nakagami, S., Suzuki, S., Yuki, I. \& Ohkawa, K. Electrospinning and post-spun chain conformations of synthetic, hydrophobic poly( $\alpha$-amino acid)s. Polymers (Basel, Switz.) 12, 327, doi:10.3390/polym12020327 (2020).

26 Maiti, D. K., Bhattacharjee, R., Datta, A. \& Banerjee, A. Modulation of Fluorescence 
Resonance Energy Transfer Efficiency for White Light Emission from a Series of StilbenePerylene Based Donor-Acceptor Pair. J. Phys. Chem. C 117, 23178-23189, doi:10.1021/jp409042p (2013).

27 Chen, S. The HPLC stereoselective resolution of N-2,4-dinitrophenylated (DNP) aminecontaining enantiomers on teicoplanin bonded phase using the methanol-based mobile phase. Chromatographia 59, 173-180, doi:10.1365/s10337-003-0126-3 (2004).

28 Cherng, Y.-J. Efficient Nucleophilic Substitution Reaction of Aryl Halides with Amino Acids Under Focused Microwave Irradiation. Tetrahedron 56, 8287-8289, doi:https://doi.org/10.1016/S0040-4020(00)00739-0 (2000).

29 Badley, R. A. \& Teale, F. W. J. Resonance energy transfer in pepsin conjugates. J. Mol. Biol. 44, 71-88, doi:10.1016/0022-2836(69)90405-7 (1969).

30 Maina, F. et al. Preparation of new imidazobenzothiazole amino acid derivatives for therapeutic use as inhibitors of oncogenic signals by the Met family. US20130085143A1 (2013).

31 Hosseinzadeh, R., Mavvaji, M., Tajbakhsh, M., Lasemi, Z. \& Aghili, N. Selective Oxidation of Hydrocarbons and Alcohols Using Phen-MCM-41 as an Efficient Co-Catalyst in Combination with NHPI-Based Nano-Magnetic Catalyst. Organic Preparations and Procedures International 52, 99-109, doi:10.1080/00304948.2020.1716434 (2020).

32 Meggers, E., Kusch, D. \& Giese, B. An Efficient Synthesis of Enantiomerically Pure $\Delta$ - and $\Delta$ Ruthenium(II)-Labelled Oligonucleotides. Helvetica Chimica Acta 80, 640-652, doi:https://doi.org/10.1002/hlca.19970800303 (1997).

33 Koft, E. \& Case, F. H. Substituted 1,10-Phenanthrolines, XII. Benzo and Pyrido Derivatives1. The Journal of Organic Chemistry 27, 865-868, doi:10.1021/jo01050a042 (1962).

34 Adamson, K., Dolan, C., Moran, N., Forster, R. J. \& Keyes, T. E. RGD Labeled Ru(II) Polypyridyl Conjugates for Platelet Integrin $\alpha \mathrm{IIb} \beta 3$ Recognition and as Reporters of Integrin Conformation. Bioconjugate Chemistry 25, 928-944, doi:10.1021/bc5000737 (2014).

35 Cruz, A. J., Kirgan, R., Siam, K., Heiland, P. \& Rillema, D. P. Photochemical and photophysical properties of ruthenium(II) bis-bipyridine bis-nitrile complexes: Photolability. Inorg. Chim. Acta 363, 2496-2505, doi:10.1016/j.ica.2010.04.014 (2010).

36 Keller, S. G. et al. Light-driven electron injection from a biotinylated triarylamine donor to $[\mathrm{Ru}$ (diimine)3]2+-labeled streptavidin. Org. Biomol. Chem. 14, 7197-7201, doi:10.1039/C6OB01273F (2016). 